\title{
Phosphorus limitation of algae living in iron-rich, acidic lakes
}

\section{Elly Spijkerman*}

University of Potsdam, Department of Ecology and Ecosystem Modelling, Am Neuen Palais 10, 14469 Potsdam, Germany

\begin{abstract}
Very acidic lakes (pH 2.3 to 3.2) have developed in abandoned open cast mines of eastern Germany. Recent research has shown that growth of Chlamydomonas acidophila inhabiting one of these lakes was likely limited by inorganic phosphorus (P). Although most measurements of soluble reactive phosphorus (SRP) concentrations do not identify $\mathrm{P}$ as the factor limiting growth (i.e.

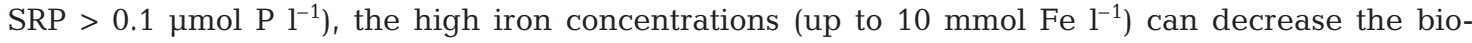
available $\mathrm{P}$ fraction by complexation, or can lower P-uptake rates by adsorption processes. To test for P-limitation, 4 lakes (Lakes 107, 111, 113 and 117) were sampled 5 times in 2006 to measure SRP, particulate phosphate, particulate carbon, dissolved organic carbon, chlorophyll a concentration, algal abundance, maximum $\mathrm{P}$ uptake rate, and phosphatase activity; P-enrichment experiments were also conducted. All results suggest that algal growth was P limited, at least during some part of the year, even in the lake with the highest SRP concentration (Lake 107: $1 \mu \mathrm{mol} \mathrm{P}^{-1}$ ). In P-enrichment experiments, $C$. acidophila always became the dominant species, suggesting that of all species present, this was the most P-limited. In contrast to expectations, the extent of algal P-limitation in these very acidic lakes could not be explained by SRP and iron concentrations.
\end{abstract}

KEY WORDS: Acid mine drainage - Algal community - Chlamydomonas - Metal-rich lakes · P-availability

\section{INTRODUCTION}

Algae living in very acidic lakes ( $\mathrm{pH} 2.3$ to 3.2 ) face several stress factors that can potentially lower their in situ growth rates. In some of the very acidic mining lakes found in eastern Germany, phosphorus (P) has been proposed as the growth limiting factor (Beulker et al. 2002, Spijkerman et al. 2007). In contrast, nitrogen concentrations in the acidic lakes are sufficiently high (Bissinger et al. 2000) to preclude N-limitation. Inorganic nitrogen in the acidic lakes is mainly present as ammonium $\left(\mathrm{NH}_{4}^{+}\right)$because nitrification rates are inhibited at low pH (Kleeberg et al. 2006). In addition to P-limitation, inorganic carbon limitation has been suggested (Beulker et al. 2002, Tittel et al. 2005). At very low $\mathrm{pH}$, virtually no bicarbonate is present in solution, and $\mathrm{CO}_{2}$ is the only inorganic carbon source. In Lake 111 (eastern Germany), concentrations of $\mathrm{CO}_{2}$ are high in the lower water strata (400 to $900 \mu \mathrm{mol} \mathrm{C}$ $\mathrm{l}^{-1}$ ), and low in the upper water strata of the lake (i.e.

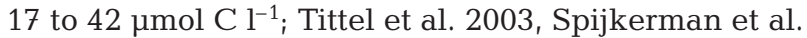
2007). There is a continuous out-gassing of $\mathrm{CO}_{2}$ throughout the year, except during ice-cover when $\mathrm{CO}_{2}$ accumulates under ice. Under optimal conditions in laboratory cultures, increased growth rates in response to $\mathrm{CO}_{2}$ aeration have been observed (Tittel et al. 2005, Spijkerman 2008). The increased growth rates result from a physiological acclimation and the redirection of metabolic energy used to acquire $\mathrm{C}$ at low $\mathrm{CO}_{2}$ concentrations into growth under enhanced $\mathrm{CO}_{2}$ conditions (Spijkerman 2005, 2008).

P-enrichment experiments resulted in an increased photosynthetic quantum yield after $24 \mathrm{~h}$ in algae from Lake 111 and Lake 117, but not in those from Lake 107 (Beulker et al. 2002). Using a wide variety of methods, P-limited growth of Chlamydomonas acidophila was detected in Lake 111 for a part of the year and at several depths (Spijkerman et al. 2007). C. acidophila is found in a number of very acidic lakes (e.g. Gyure et al. 1987, Doi et al. 2003, Gerloff-Elias et al. 2005), and 
in the German mining lakes it is the main photoautotrophic phytoplankter (Kamjunke et al. 2004). Although species diversity in the acidic lakes is low, taxa from a number of algal classes are present, including several diatom species, chrysophytes, euglenophytes and chlorophytes (Lessmann et al. 2000).

The concentration of iron present in the acidic lakes is high and consists mainly of ferric iron, with up to only $10 \%$ being reduced ferrous iron (Friese et al. 2002). The high iron concentrations strongly buffer the lake water between a pH of 2 and 4 . The ferric iron phosphate complex is more insoluble than ferrous phosphate (Stumm \& Morgan 1970), and consequently part of the soluble reactive phosphorus (SRP) might consist of ferric phosphate complexes not available for algal growth. Therefore, high SRP concentrations might not translate to high concentrations of $\mathrm{P}$ for algal growth. Furthermore, ferric iron concentrations of $5 \mathrm{mmol} \mathrm{l}^{-1}$ are considered toxic for algal assemblages in a very acidic river in Spain (Rowe et al. 2007). Consequently, the defense mechanisms of algae that overcome toxic iron conditions might consume ATP, resulting in increased metabolic costs (Messerli et al. 2005) and a consequent decrease in population fitness. In addition, P-capturing processes may be inhibited by high iron concentrations that cause Fe to adsorb to the cell surface. As a first study on the possible toxicity of iron under very acidic conditions and to test for a possible P limitation in Fe-rich lakes, 4 lakes with different iron concentrations were sampled on 5 occasions during the year 2006 to test (1) whether the algal community was P-limited and (2) whether a P-limitation was related to the Fe and/or SRP concentrations.

\section{MATERIALS AND METHODS}

Field sampling. From April to October 2006, 4 lakes (Lakes 107, 111, 113 and 117; 51 ${ }^{\circ} 29^{\prime} \mathrm{N}, 1^{\circ} 38^{\prime} \mathrm{E}$ ) were sampled every $6 \mathrm{wk}$ in the littoral zone where the water is approximately $1 \mathrm{~m}$ deep. The sampling dates were 3 May, 12 June, 19 July, 4 September and 19 October. On 3 May, Lake 113 was not sampled, due to access restrictions. Directly after sampling, water was either filtered through a $10 \mu \mathrm{m}$ zooplankton net (to give a 'total fraction' containing algae and bacteria) or through a Whatman GF/C filter followed by an acid drained 1.2- $\mu \mathrm{m}$ Nuclepore filter (to give the ' $<1.2 \mu \mathrm{m}$ fraction' containing only single-celled bacteria), and/or an acid drained $0.2 \mu \mathrm{m}$ Nuclepore filter (to give the '<0.2 $\mu \mathrm{m}$ fraction', or soluble fraction). This procedure prepared fractions containing phytoplankton, bacteria or dissolved substances only for chemical analysis. The zooplankton net eliminated rotifers, which are important predators in the lake (Weithoff 2004), but did not eliminate heliozoans or Ochromonas sp. The mixotrophic alga Ochromonas sp. preys on Chlamydomonas acidophila in these acidic lakes (Tittel et al. 2003)

Analyses. The total fraction was filtered over an acid drained $0.2 \mu \mathrm{m}$ track etch filter, which was subsequently used for particulate phosphorus analysis. The filter was oxidized with $\mathrm{K}_{2} \mathrm{~S}_{2} \mathrm{O}_{8}$ and $\mathrm{H}_{2} \mathrm{SO}_{4}$ and autoclaved for $20 \mathrm{~min}$. Soluble reactive phosphorus (SRP) was analysed from the $<0.2 \mu \mathrm{m}$ fraction. Phosphorus was determined in both fractions by a reduction of the molybdate-complex with ascorbic acid (Murphy \& Riley 1962). On the first sampling date, i.e. 3 May, no phosphorus determinations were made.

Sub-samples of all fractions were fixed with Lugol's solution ( $0.2 \%$ f.c.) and the algal cells were counted by inverted microscopy. Bacteria were stained with acridine orange and counted under a fluorescence microscope after filtration onto black membrane filters.

Dissolved organic carbon (DOC) concentrations were determined in the $<0.2 \mu \mathrm{m}$ fraction using an infra-red analysis method (HighTOC). For particulate organic carbon (POC) concentrations, water was filtered through pre-combusted glass fibre filters (Whatman GF/F), dried at $50^{\circ} \mathrm{C}$ for $1 \mathrm{wk}$ and measured in a carbon analyser (HighTOC). A proportion of the filters was analysed on an NCS-2500 analyzer (ThermoQuest) to estimate particulate organic nitrogen concentration (PON).

Metal concentrations (iron and aluminium) in the water were determined using inductively coupled plasma optical emission spectroscopy (ICP - OES JY 38 PLUS, HORIBA Jobin Yvon S.A.S). The certified reference material 'NIST - SRM 1640 - Trace Elements in Natural Water' was used to verify the accuracy of ICP-OES analyses.

For determination of chl a concentrations, total fraction lake water was filtered through Whatman GF/F filters, immediately rinsed with $0.1 \mathrm{~mol}$ ammonium acetate $1^{-1}$ (Ruecker \& Liepelt 2003) and extracted in $90 \%$ ethanol at $60^{\circ} \mathrm{C}$ in the dark. The extract was measured the following day using a fluorometer (Turner TD-700, F4T4.B2 lamp, excitation: $436 \mathrm{~nm}$ emission: $680 \mathrm{~nm}$ ), which was calibrated with a commercial chl a standard (Sigma).

P-enrichment assays. Two sets of eight $300 \mathrm{ml}$ Erlenmeyer flasks were filled with $100 \mathrm{ml}$ of total and $<1.2 \mu \mathrm{m}$ water fractions, respectively. Four of the 8 flasks were enriched with $10 \mu \mathrm{M} \mathrm{H}_{3} \mathrm{PO}_{4}$ (f.c.). The addition of the phosphoric acid did not change the $\mathrm{pH}$ of the lake water. All Erlenmeyer flasks were placed in a climate chamber at $20^{\circ} \mathrm{C}$, under approximately $100 \mu \mathrm{mol}$ photons $\mathrm{m}^{-2} \mathrm{~s}^{-1}$, with a 16:8 h L:D cycle. After $7 \mathrm{~d}$ of incubation, biomass was determined in all flasks by measuring the optical density at $750 \mathrm{~nm}$ in a 
spectrophotometer using a $5 \mathrm{~cm}$ long cuvette (UV2401PC, Shimadzu) and by measuring the in situ fluorescence of chl $a$ in a fluorometer (Turner TD-700, for settings, see chl a determination). To calculate the increase in biomass, the biomasses in the flasks without $\mathrm{P}$ was subtracted from those with $\mathrm{P}$. In a selection of the samples, algal cells were counted under the microscope.

P-uptake rates. Two sets of four $250 \mathrm{ml}$ Erlenmeyer flasks were filled with $100 \mathrm{ml}$ of total and $<1.2 \mu \mathrm{m}$ fractions, respectively, and placed in the light (approximately $85 \mu \mathrm{mol} \mathrm{m} \mathrm{m}^{-2} \mathrm{~s}^{-1}$ inside the flask). Over a period of $1 \mathrm{~h},{ }^{33} \mathrm{P}$ uptake was measured by the addition of $\mathrm{H}_{3}{ }^{33} \mathrm{PO}_{4}$ (on average $61 \mathrm{kBq}$ per sample, $111 \mathrm{GBq}$ $\mathrm{mmol}^{-1}$ specific activity, GE Healthcare) diluted in stock solutions of $500 \mu \mathrm{mol} \mathrm{Na} / \mathrm{K}_{2} \mathrm{HPO}_{4} \mathrm{l}^{-1}$. The first measurement was made after $10 \mathrm{~min}$ to allow for proper mixing. Uptake was terminated by filtration through $1.2 \mu \mathrm{m}$ pore-size cellulose acetate filters for the total fraction and through $0.2 \mu \mathrm{m}$ cellulose acetate filters for the $<1.2 \mu \mathrm{m}$ fraction, and rinsing with $0.2 \mathrm{~mol}$ $\mathrm{LiCl} \mathrm{l}^{-1}$. The filters were embedded in Ultima Gold (Packard) and counted in a liquid scintillation analyser (2300 TR Packard). Maximum P uptake was measured in triplicate using a final concentration of 5 or $10 \mu \mathrm{mol}$ $\mathrm{P}^{-1}$. One additional replicate was enriched with formaldehyde $(0.37 \%$ f.c.) and served as a control. The 'uptake rate' of the formaldehyde killed sample was subtracted from that of the live samples and was $<5 \%$ of the rates of the live samples in most cases.

Phosphatase activity. Phosphatase activity was measured using 6,8-difluoro-4-methylumbelliferyl phosphate (difMUP, Molecular Probes) and a fluorometer (Turner TD-700, excitation: $365 \mathrm{~nm}$, emission: 410 to $610 \mathrm{~nm})$. The reaction solution contained $20 \mathrm{mmol} \mathrm{Na}-$ acetate $\mathrm{l}^{-1}, 20 \mathrm{mmol}$ 4-(2-Hydroxyethyl)piperazine-1ethanesulphonic acid (Hepes) $\mathrm{l}^{-1}$ and $2 \mathrm{mmol} \mathrm{MgCl}_{2}$ $\mathrm{l}^{-1}$. This solution was brought to $\mathrm{pH} 2.7,6.0$ and 9.0 to measure the activity at the lake water $\mathrm{pH}$ and at 2 previously determined optima (Spijkerman et al. 2007). Activity was measured only in total fractions. Acid phosphatase from potato (EC 3.1.3.2, Sigma) and alkaline phosphatase from Escherichia coli (EC 3.1.3.1, Sigma) were similarly treated and served as standards.

Table 1. $\mathrm{pH}$, total iron (Fe), total aluminium (Al) and dissolved organic carbon (DOC) concentrations (all in $\mu \mathrm{mol} \mathrm{l}^{-1}$ ) in 4 very acidic lakes. Means of 5 sampling occasions \pm SE are shown

\begin{tabular}{|ccccc|}
\hline Lake & $\mathrm{pH}$ & Fe (total) & $\mathrm{Al}$ (total) & DOC \\
\hline 107 & $2.3 \pm 0.1$ & $9245 \pm 746$ & $2144 \pm 171$ & $269 \pm 18$ \\
113 & $2.6 \pm 0.0$ & $3122 \pm 316$ & $1180 \pm 16$ & $429 \pm 136$ \\
111 & $2.6 \pm 0.0$ & $2176 \pm 162$ & $1061 \pm 53$ & $149 \pm 26$ \\
117 & $3.2 \pm 0.0$ & $98 \pm 9$ & $22 \pm 3$ & $157 \pm 15$ \\
\hline
\end{tabular}

The increase in fluorescence was measured over a $2 \mathrm{~min}$ period after mixing $0.5 \mathrm{ml}$ of $25 \mu \mathrm{mol}$ difMUP ${ }^{-1}$, $0.5 \mathrm{ml}$ of sample or standard and $1.5 \mathrm{ml}$ of Hepes solution. Fluorescence changes over time and fluorescence intensity after 2 min was calibrated to the acid phosphatase at $\mathrm{pH} 2.7$ and 6.0 and to alkaline phosphatase at $\mathrm{pH}$ 9.0. The $\mathrm{pH}$ remained stable during the assay. All measurements were at least performed in triplicate. Tests of significance were performed with SPSS (version 15.0). To test for normal distribution of the data, a Kolmogorov-Smirnov test was used, and for homogeneity of variances a Levene's test was performed.

\section{RESULTS}

The $\mathrm{pH}$ and concentrations of aluminium and organic carbon did not vary over the year and therefore mean concentrations of all sampling events are given in Table 1. The lowest $\mathrm{pH}$ was always found in Lake 107 (pH 2.3); a pH of 2.6 was measured in Lakes 113 and 111, and the highest $\mathrm{pH}$ of 3.2 occurred in Lake 117. Only in Lake 107 did concentrations of Fe increase with time (from 394 to $629 \mathrm{mg} \mathrm{Fe} \mathrm{l}^{-1}$ ); there were no increases in the other 3 lakes. Therefore, mean Fe concentrations over the year were calculated for all 4 lakes (Table 1). The $\mathrm{pH}$ of lake water was negatively correlated with the concentration of dissolved total iron and aluminium (Pearson correlation, $\mathrm{r}=-0.82$ and -0.95 for $\mathrm{Fe}$ and $\mathrm{Al}$, respectively; $\mathrm{n}=19, \mathrm{p}<0.001$ for both). Only DOC concentration among physicochemical variables tested had no correlation with $\mathrm{pH}$; the highest DOC concentration was found in Lake 113, followed by Lake 107 and the lowest in Lakes 117 and 111 (Pearson correlation $\mathrm{r}=-0.28, \mathrm{n}=19, \mathrm{p}=0.25$ ).

Concentrations of SRP may provide an indication of P-limitation in algae. SRP concentrations were highest in Lake 107 (ranging between 0.7 and $0.85 \mu \mathrm{mol} \mathrm{P} \mathrm{l}^{-1}$ ), moderate in Lakes 113 and 111 (ranging between 0.3 and $0.5 \mu \mathrm{mol} \mathrm{P}^{-1}$ ), and lowest in Lake 117 ( ranging between 0.2 and $0.25 \mu \mathrm{mol} \mathrm{P} \mathrm{l}^{-1}$ ) (Pearson correlation of SRP by $\mathrm{pH}, \mathrm{r}=-0.85, \mathrm{n}=16, \mathrm{p}<0.001$ ) (Fig. 1A). In addition, lake water $\mathrm{pH}$ was negatively correlated with total phosphorus concentration (Pearson $\mathrm{r}=-0.83, \mathrm{n}=$ $16, \mathrm{p}<0.001$, data not shown). There was no difference in particulate phosphorus (PP) among lakes, and concentrations of particulate phosphate were low in all 4 water bodies (Pearson correlation of PP by $\mathrm{pH}, \mathrm{r}=0.04$, $\mathrm{n}=16, \mathrm{p}=0.90$ ) (Fig. 1B). Over the investigation period, there were no clear seasonal fluctuations in either SRP or PP; however, PP was lowest on 19 October in all 4 lakes.

Chl a concentrations were low in all lakes, ranging between 0.1 and $8.2 \mu \mathrm{g} \mathrm{l}^{-1}$ (Fig. 2). There were no clear seasonal patterns in chl a concentrations in any of the 


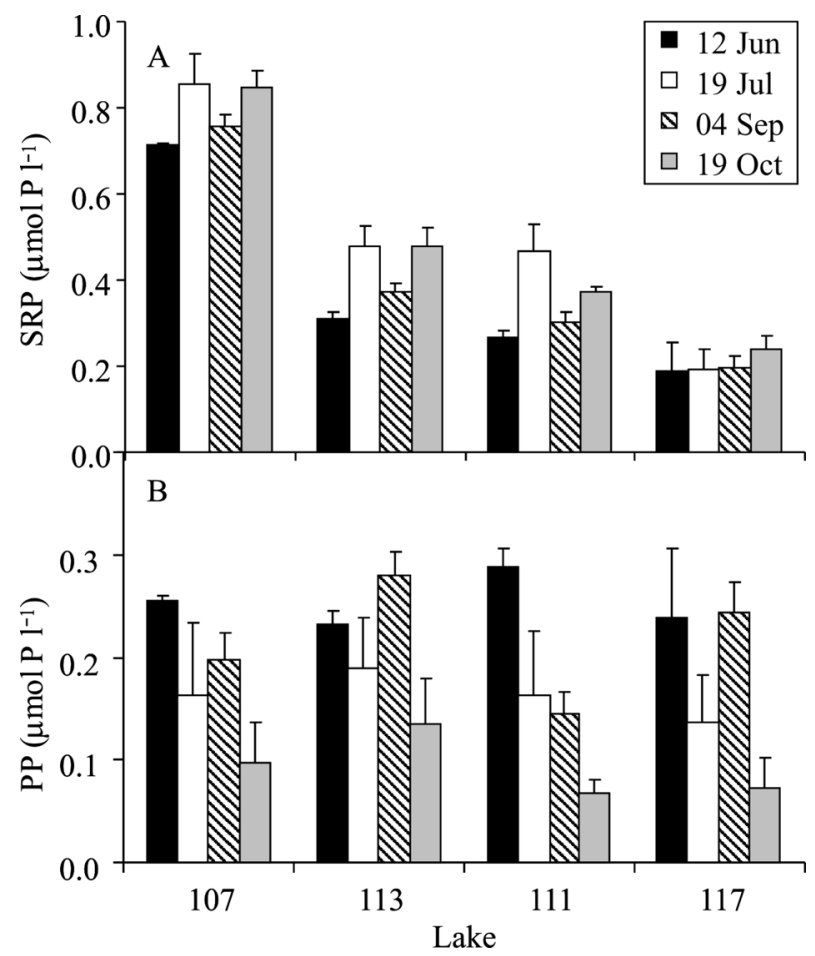

Fig. 1. (A) concentrations of soluble reactive phosphorus (SRP) and (B) particulate phosphorus (PP) in 4 acidic lakes $(107,113,111$ and 117) on 4 sampling dates in 2006. Means + $\mathrm{SD}, \mathrm{n}=4$, are shown. On the first sampling date (3 May), no phosphorus determinations were made

lakes, although, remarkably, the lowest concentrations were determined on 19 July in all 4 lakes. There was no correlation between chl $a$ and SRP concentrations (Pearson, $\mathrm{r}=0.15, \mathrm{n}=16, \mathrm{p}=0.57$, data not shown). In addition, chl a concentrations did not correlate with PP (Pearson, $\mathrm{r}=0.005, \mathrm{n}=16, \mathrm{p}=0.98$, data not shown) nor with $\mathrm{pH}$ (Pearson, $\mathrm{r}=-0.25, \mathrm{n}=19, \mathrm{p}=0.31$, data not shown).

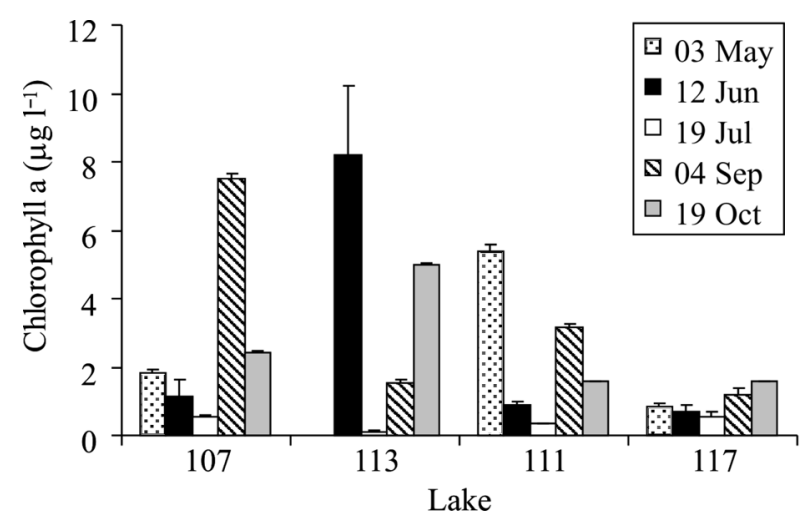

Fig. 2. Chl a concentrations in Lakes 107, 113, 111 and 117 in 2006. Means $+\mathrm{SD}, \mathrm{n}=4$, are shown. If no $\mathrm{SD}$ is visible, the value was too small to be seen. On 3 May, it was not possible to sample Lake 113

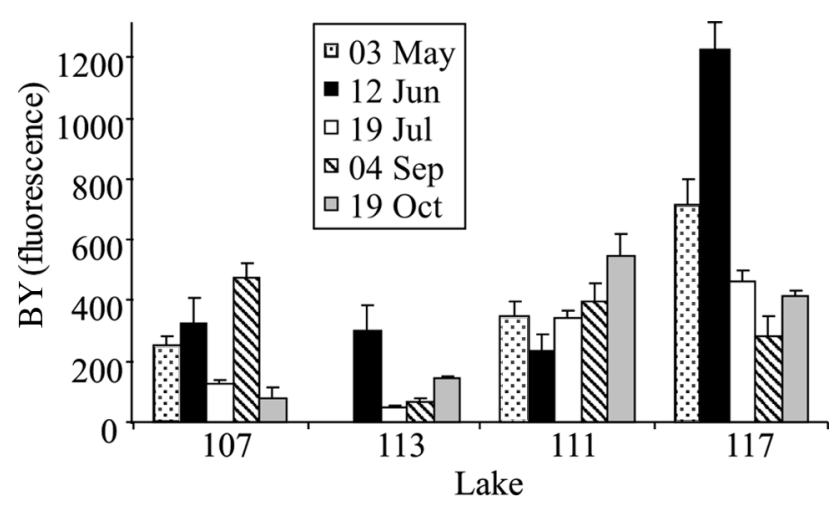

Fig. 3. Biomass yield (BY) in P-enriched minus non-treated lake water after $1 \mathrm{wk}$ of incubation; BY measured by chl a fluorescence. Means $+\mathrm{SD}, \mathrm{n}=4$, are shown

After 1 wk incubation in P-enriched lake water, a much higher biomass was found than in the nontreated lake water on nearly all sampling occasions and in all lakes (Fig. 3). In Lake 117, the biomass yield was highest on average, and there was a clearly enhanced biomass yield in Lakes 111 and 107 on several occasions. The increase in biomass was lowest in Lake 113, where a clearly enhanced biomass occurred only on 12 June. The relative biomass increase (biomass in $+\mathrm{P}$ flasks divided by that in $-\mathrm{P}$ flasks) was significantly higher than 1 on all occasions in all lakes, and ranged between 6 and 60 (data not shown).

When increases in fluorescence were relatively low, the increase in biomass measured as optical density at $750 \mathrm{~nm}$ was significant, suggesting that organisms with low chl a content were dominant. To test whether this non-fluorescent biomass was the result of bacterial growth, replicate enrichment incubations were performed with the $<1.2 \mu \mathrm{m}$ fraction that contained only bacteria. In these incubations, bacteria in Lake 117 also increased their biomass after P-enrichment, whereas the bacteria in the other lakes did not respond to P-addition (ANOVA, $F_{1,17}=11.6, \mathrm{p}<0.005$; Table 2).

Table 2. Biomass yield (BY) in P-enriched minus non-treated lake water after 1 wk of incubation, measured by optical density in $1.2 \mu \mathrm{m}$ filtrate of water samples taken on 5 occasions in 4 lakes in 2006. Means $\times 1000 \pm \mathrm{SD}, \mathrm{n}=4$, are shown; negative values imply that biomass decreased over the time period. On 3 May, it was not possible to sample Lake 113

\begin{tabular}{|rrrrrr|}
\hline Lake & 3 May & 12 Jun & 19 Jul & 4 Sep & 19 Oct \\
\hline 107 & $-1 \pm 1$ & $-3 \pm 1$ & $-2 \pm 3$ & $12 \pm 1$ & $18 \pm 20$ \\
113 & & $-1 \pm 2$ & $-20 \pm 3$ & $3 \pm 1$ & $2 \pm 28$ \\
111 & $6 \pm 2$ & $0 \pm 1$ & $-14 \pm 14$ & $1 \pm 1$ & $4 \pm 18$ \\
117 & $33 \pm 1$ & $7 \pm 1$ & $10 \pm 1$ & $16 \pm 2$ & $21 \pm 31$ \\
\hline
\end{tabular}


The biomass yield from the $<1.2 \mu \mathrm{m}$ fraction was much lower than that of the total fraction (an average of 50fold lower; data not shown) which may be a result of DOC limitation of bacteria in the $<1.2 \mu \mathrm{m}$ fraction. In the experiment performed with the total fraction, bacterial growth would have been enhanced through increased DOC concentrations derived from algal growth. Therefore, bacterial counts were determined in the P-enrichment experiments with the total fraction, which showed that increases in bacterial and algal abundance were not significantly correlated in any of the lakes.

The biomass yield expressed as the increase in chl a fluorescence did not correlate with SRP concentrations in the lakes, nor with TP (Pearson, $r=-0.41, \mathrm{p}=0.11$ for both, data not shown).

The greatest proportional abundance of Chlamydomonas acidophila was in Lake 117 (ranging from 12 to $49 \%$ ) and in September and October in Lake 111 (16 and $38 \%$, respectively; Fig. 4A); on other occasions and in other lakes, there were lower percentages of $C$. acidophila cells (ranging between 2 and $13 \%$ ). In Lake 113, Ochromonas sp. was especially dominant among algal species (ranging from 42 to $89 \%$ of total algal numbers); this species was also dominant in other lakes, (with abundances ranging from 30 to $71 \%$ of total algal numbers, Fig. 4B). Another important species in some of the samples was a filamentous green alga, which may have been Zygogonium ericetorum (Kleeberg et al. 2006) or Gonatozygon sp. (Desmidiaceae); these filaments were only a few micrometers in diameter, and were usually relatively short. After $1 \mathrm{wk}$ in P-enriched enclosures, C. acidophila was the dominant species in most cases, yielding up to $90 \%$ of the total cell number in some instances (Fig. 4C). Only on occasions when the ratios of Ochromonas sp. to C. acidophila cells were $>10$, were $C$. acidophila densities lower at the end of the experiment (e.g. Lake 113, Fig. 4). In contrast, a relatively high abundance of Ochromonas sp. cells developed in these Erlenmeyer flasks after P-enrichment (Fig. 4D).

The P-uptake rates of the algal communities were predominantly low and were significant only in Lake 117 (ranging from 100 to $1500 \mu \mathrm{mol} \mathrm{P} \mathrm{mol} \mathrm{C} \mathrm{C}^{-1} \mathrm{~h}^{-1}$ ) and on single occasions in Lakes 113 and 111 (Fig. 5A). The $\mathrm{P}$-uptake rates positively correlated with the numerical ratio of Chlamydomonas acidophila cells to total number of phytoplankton (Pearson correlation, $\mathrm{r}=0.79, \mathrm{p}<$ 0.001), but not with the cell density of $C$. acidophila ( $\mathrm{r}$ $=0.25, p=0.29$ ). In water from Lake 113, a significant P-uptake rate occurred on 19 July, but the uptake rates were negative on later dates. There was a negative P-

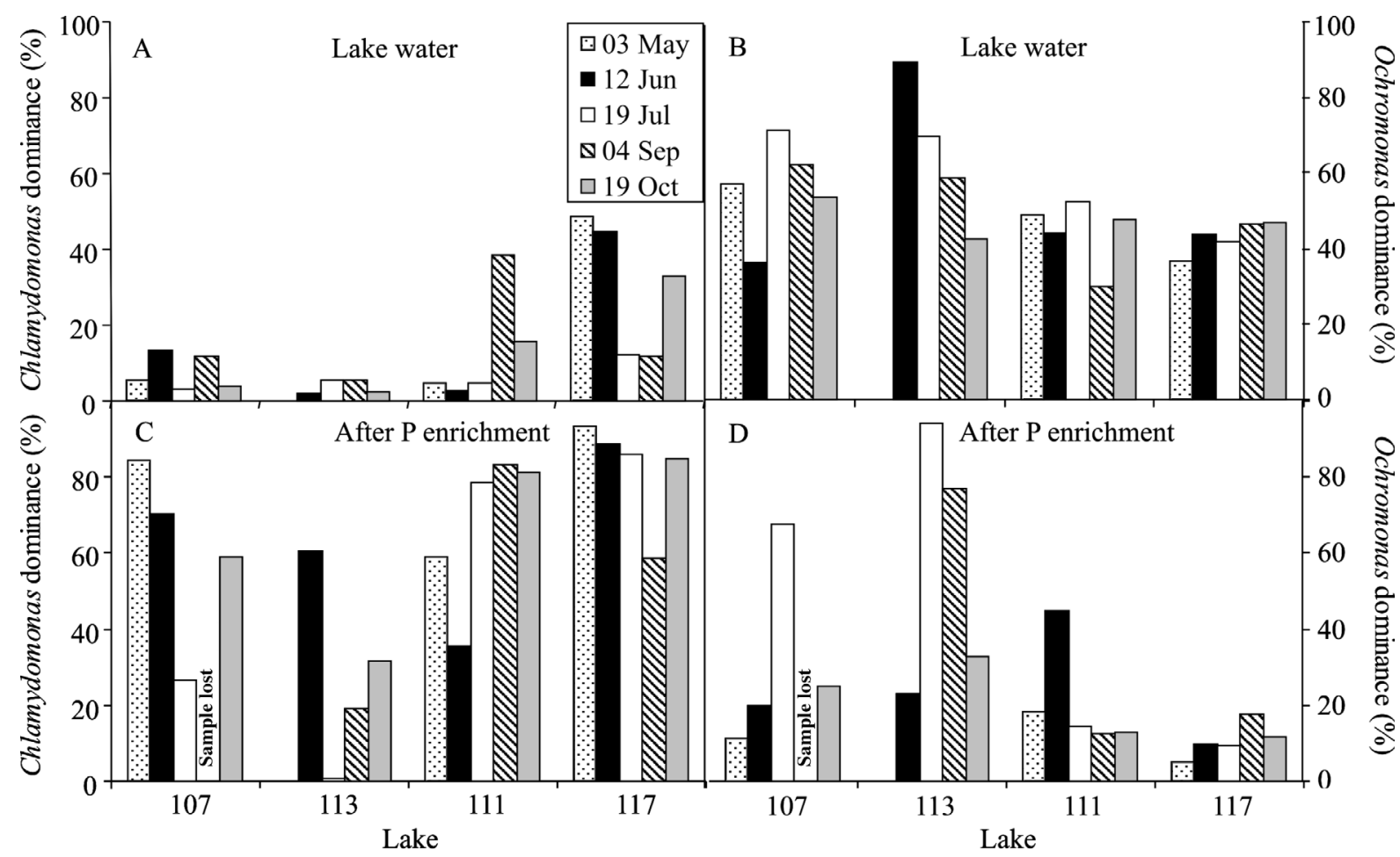

Fig. 4. Percentage contribution of $(\mathrm{A}, \mathrm{C})$ Chlamydomonas acidophila and $(\mathrm{B}, \mathrm{D})$ Ochromonas sp. to total cell number in $(\mathrm{A}, \mathrm{B})$ water of Lakes 107, 113, 111 and 117 and $(C, D)$ after 1 wk of experimental P-enrichment. The 4 September sample from the P enrichment experiment was lost, and no sample was collected on 3 May from Lake 113 

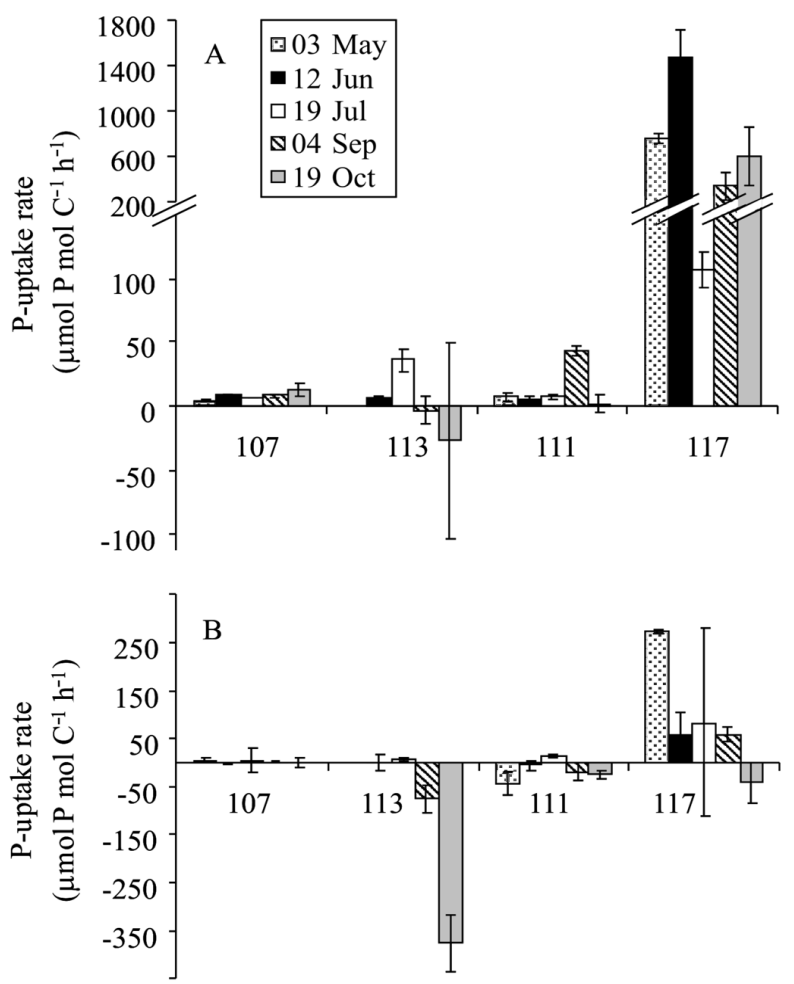

Fig. 5. P-uptake rates by (A) the algal community (total fraction) and (B) bacterial community (<1.2 $\mu \mathrm{m}$ fraction) in 4 acidic lakes $(107,113,111$ and 117$)$ on 5 sampling occasions in 2006. Means $\pm \mathrm{SD}, \mathrm{n}=3$, are shown uptake rate in the Lake 113 bacterial fraction on 4 September and 19 October (Fig. 5B), and this also occurred in other lakes. In the bacterial fraction, significant Puptake rates occurred only in water from Lake 117. Uptake rates were usually lower in the bacterial fraction than in the algal community, and the algal community took up $\mathrm{P}$ on average 4 times faster (when positive rates were taken into account). However, on some occasions the mean uptake rates of the bacterial and algal fractions were comparable (e.g. on 3 May in Lake 107).

No phosphatase activity was detected at pH 2.7 (data not shown). The highest enzyme activity at pH 9.0 was measured in Lake 107, and activities were lower in the other 3 lakes (ANOVA, $F_{3,190}=57, \mathrm{p}<0.001$, Tukey HSD, $\mathrm{p}<0.001$ ) (Fig. 6A). In contrast, highest phosphatase enzyme concentrations at $\mathrm{pH} 9.0$ occurred in water from Lakes 117, 111 and 113, rather than in Lake 107 water (ANOVA, $F_{3,185}=16, \mathrm{p}<0.001$, Tukey HSD, $\mathrm{p}<0.001$ ) (Fig. 6B). The measurements at $\mathrm{pH} 6.0$ were different (Fig. 6C,D), with approximately 50-fold higher activities (but lower concentrations) than at $\mathrm{pH}$ 9.0. At $\mathrm{pH} 6.0$, phosphatase activities and concentrations were highest in Lake 117, intermediate in Lake 111 and Lake 113 and lowest in Lake 107 (ANOVA, $F_{3,190}=37, \mathrm{p}<0.001$, Tukey HSD, $\left.\mathrm{p}<0.001\right)$ (Fig. 6C,D). Significant seasonal variation in phosphatase enzyme activity and concentration were

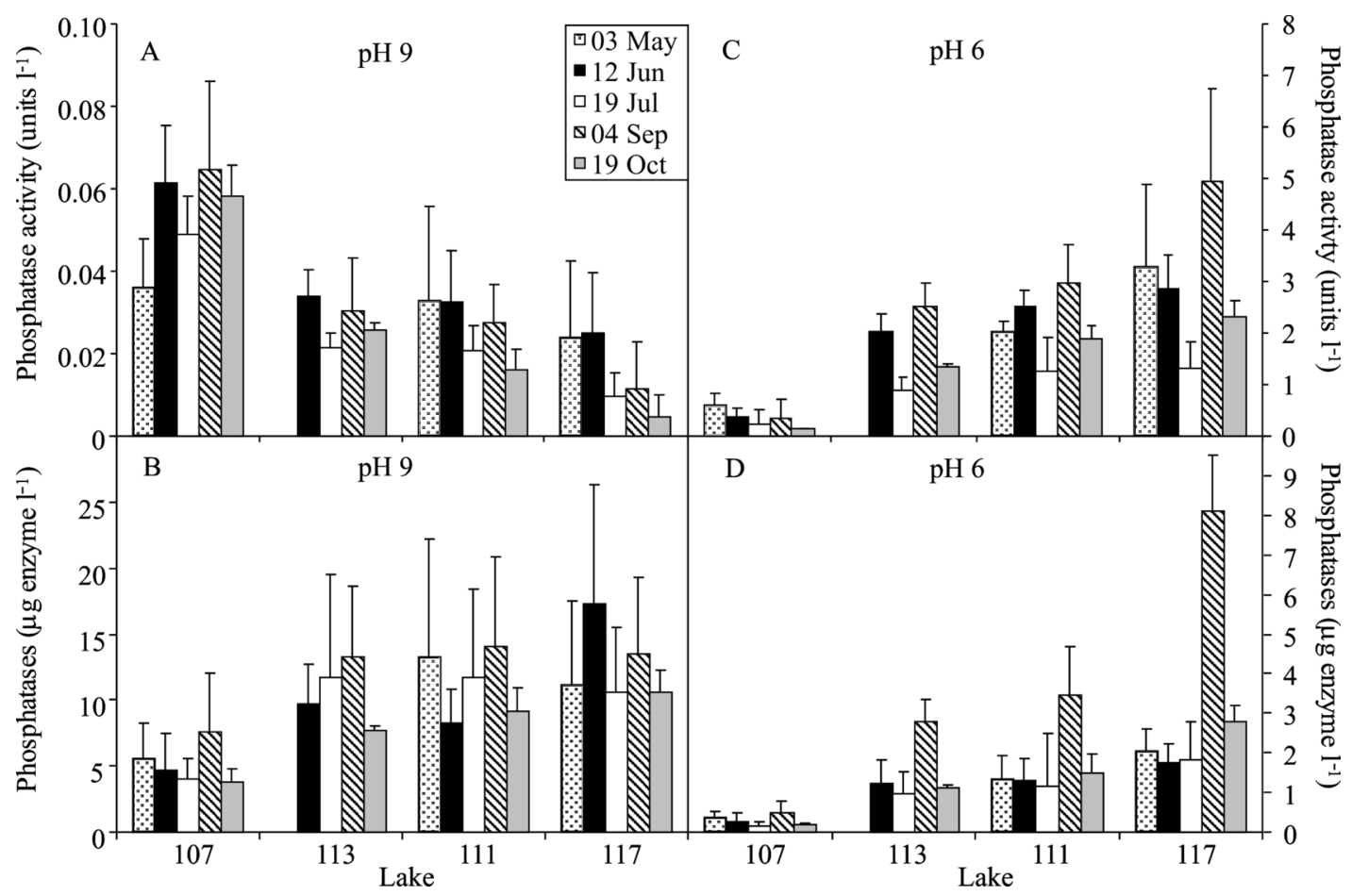

Fig. 6. (A,C) Phosphatase activity, and (B,D) the concentration of enzymes in samples from Lakes 107, 113, 111, and 117 sampled on 5 occasions in 2006 and measured at $(\mathrm{A}, \mathrm{B}) \mathrm{pH} 9.0$ or $(\mathrm{C}, \mathrm{D}) \mathrm{pH}$ 6.0. One unit will hydrolyze 1 umol of 4 -nitrophenyl phosphate $\mathrm{min}^{-1}$ at $\mathrm{pH} 10.4$ (for $\mathrm{pH}$ ) and at $\mathrm{pH} 4.8$ (for $\mathrm{pH}$ ) at $37^{\circ} \mathrm{C}$. Means $+\mathrm{SD}, \mathrm{n}=3$, are shown 
Table 3. C:N and C:P molar ratios of the total fraction in 4 lakes sampled on 5 occasions in 2006. On 3 May particulate phosphorus was not determined; hence no C:P ratios were calculated, and also on that date no sample was collected from Lake 113

\begin{tabular}{|ccccccccccc|}
\hline \multirow{2}{*}{ Lake } & \multicolumn{1}{c}{ 3 May } & \multicolumn{1}{c}{ 12 Jun } & \multicolumn{2}{c|}{ 19 Jul } & \multicolumn{2}{c|}{ 4 Sep } & \multicolumn{2}{c|}{ 19 Oct } \\
& C:N & C:N & C:P & C:N & C:P & C:N & C:P & C:N & C:P \\
\hline 107 & 5.6 & 7.5 & 391 & 2.4 & 432 & 5.2 & 821 & 3.8 & 825 \\
113 & & 4.6 & 731 & 5.4 & 398 & 8.3 & 529 & 5.2 & 774 \\
111 & 9.9 & 2.8 & 387 & 5.8 & 405 & 7.1 & 820 & 5.8 & 975 \\
117 & 9.8 & 20.5 & 250 & 7.2 & 477 & 12.5 & 413 & 6.0 & 898 \\
& & & & & & & & & & \\
\hline
\end{tabular}

detected at $\mathrm{pH}$ 6, with highest values in September $\left(\right.$ ANOVA, $F_{4,189}=15, \mathrm{p}<0.001$, Tukey HSD, $\mathrm{p}<0.001$ ) (Fig. 6C,D); I am not aware of any biological explanation for this finding.

Molar C:N ratios ranged between 2.4 and 20.5, and were on average $7.4( \pm 0.9 \mathrm{SE})$ a number close to the Redfield ratio (i.e. 7:1, Redfield 1934; Table 3). The highest value measured (20.5) was exceptional (measured on 6 June in Lake 117). The C:P ratios were higher than the Redfield ratio (i.e. 106:1), and on some occasions were nearly 10-fold higher.

\section{DISCUSSION}

Different methods were applied to determine whether the algae living in very acidic Fe-rich lakes were P-limited. P-enrichment experiments clearly showed P-limited conditions, even in SRP-rich lakes. The bioassays indicated that $\mathrm{P}$ was a primary limiting nutrient for growth of Chlamydomonas acidophila, and the strength of the response depended on the dominance of this species in relation to that of its predator Ochromonas sp.

\section{Abiotic factors}

In accordance with literature, lake $\mathrm{pH}$ was negatively correlated with concentrations of dissolved total iron and aluminium and with total phosphorus concentration (Packroff 2000). Dissolved organic carbon (DOC) concentrations did not correlate with $\mathrm{pH}$ (as the highest concentration of DOC was found in Lake 113). The high concentrations of DOC in Lake 113 might be the result of alkalinisation measures in the past, when organic substrates were added to stimulate internal alkalinisation caused by iron and sulphate reducing bacteria (Nixdorf et al. 2000).

All 4 lakes had similar concentrations of $\mathrm{PP}$, although SRP concentrations were approximately 4 -fold higher in Lake 107 than in Lake 117. However, in most samples, SRP concentrations were above the concentration below which $\mathrm{P}$ limitation is expected in neutral lakes

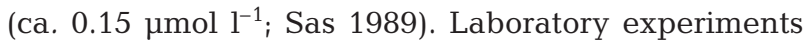
have shown that SRP concentrations in Fe-rich water are higher than $\mathrm{P}$ concentrations available for algal growth (Spijkerman 2007). Also in alkaline, hypersaline lakes containing high concentrations of sulphate, the bioavailable P concentration was lower than the SRP concentration (Waiser \& Robarts 1995), and this discrepancy was explained by high concentrations of DOC, pH and an 'unusual' ionic composition. All of the C:P ratios in the total fraction were well above the Redfield ratio (i.e. 106) and ranged between 250 and 975, which further eliminates a possible inorganic carbon limitation in the plankton. In neutral lakes, C:P ratios (molar) above 258 indicate an extreme limitation (North et al. 2007). In a study on the phytoplankton of Lake Constance, SRP concentrations were low from May to October during which time molar C:P ratios varied between 300 and 700 and phytoplankton was presumably P-limited (Hochstädter 2000). In a previous study, indications of P-limitation were found in the seston from deeper water strata of Lake 111, which had C:P ratios of 630 and 640 (data from September 2002, Spijkerman et al. 2007). The growth of the benthic green alga Zygogonium ericetorum was also considered to be mainly P-limited in Lake 117 (Kleeberg et al. 2006). In my study, the C:P ratios suggested that algae are extremely P-limited in the acidic lakes throughout the year, independently of the SRP concentration. Penrichment experiments showed that Chlamydomonas acidophila became the dominant species after enrichment, although in the lake water the relative proportion of $C$. acidophila to other algal cells was often low. However, calculations from the cell counts of $C$. acidophila and Ochromonas sp. in the P-enrichment experiments showed that the growth rate of $C$. acidophila was on average 2.5-fold higher than that of Ochromonas sp., most likely the result of the higher intrinsic growth rate of $C$. acidophila. On the other hand, Ochromonas sp. would be less P-limited as the species is an important predator of P-rich bacteria and consumes a major proportion of diel bacterial production (Schmidtke et al. 2006). Therefore, the C:P ratio of the whole algal community consists of a large number of cells (e.g. Ochromonas sp.) that are less P-limited, and the community $\mathrm{C}: \mathrm{P}$ ratio will underestimate the strength of the $\mathrm{P}$ limitation for $C$. acidophila.

The ratio between carbon and chl $a$ also indicated nutrient-limiting conditions as this ratio varied between 21 and 204 (mmol C mg chl $a^{-1}$ ). The chl a related parameters measured in this study could not have been influenced by photosynthetic bacteria because, although intensively searched for, no light absorption character- 
istics of bacterial pigments (cyanobacterial specific pigments, bacteriochlorophyll or rhodopsin) were found in the acidic lakes (Kamjunke et al. 2005). The threshold value for the carbon to chl a ratio above which a severe nutrient limitation is expected lies at 8.3 according to North et al. (2007), supporting other results suggesting that $\mathrm{P}$ limits algal growth in the acidic lakes. Comparable with a study in Lake Erie where $\mathrm{P}$ was the dominating growth limiting nutrient (North et al. 2007), TP did not correlate with chl a concentration in the acidic mining lakes of eastern Germany. This might be a consequence of the dominance of the phago-mixotrophic phytoplankter Ochromonas sp. (Tittel et al. 2003), a species with a low cellular chl a content.

\section{Biotic factors}

Many methods can be used to detect $\mathrm{P}$ limitation in algae, including $\mathrm{P}$-uptake rates, alkaline phosphatase activity and $\mathrm{P}$ enrichment experiments (Beardall et al. 2001). Nevertheless, when I used these methods in waters of acidic, Fe-rich lakes, phosphatase activity and P-uptake rate were of limited value.

$\mathrm{P}$-uptake rates demonstrated P-limitation in algae from Lake 117 . The relatively high P-uptake rates in Lake 117 were positively correlated with biomass production (based on chl a fluorescence) in P-enrichment experiments, and this suggests that $\mathrm{P}$-uptake rates were a suitable indicator of P-limitation. However, Puptake rates were negative in some cases, particularly in Lake 113. P-uptake rates were also often negative in the $<1.2 \mu \mathrm{m}$ fraction (containing only single-celled bacteria). The first time point for measuring P-uptake rates was set at $10 \mathrm{~min}$ after ${ }^{33} \mathrm{P}$ addition to accomplish good mixing, and the negative uptake rate implies rapid adsorption processes during the first $10 \mathrm{~min}$, followed by P-release during the rest of the experiment (10 to $60 \mathrm{~min}$ ). This observation implies that the fast adsorption and later release of $\mathrm{P}^{33}$ was an important process not related to algal cells but rather to an abiotic, chemical reaction. There was a slight tendency for negative P-uptake rates to correlate with high DOC concentrations, suggesting that organic carbon substances may play a role in this phenomenon. Furthermore, the rates of P-uptake measured in May and June in Lake 117 compare well with the rates for Chlamydomonas acidophila grown in Plimited laboratory cultures (compare: 90 to $120 \mathrm{mmol}$ $\mathrm{P}$ [g chl a h$]^{-1}$ under low $\mathrm{CO}_{2}$ conditions, Spijkerman 2007, with 90 to $125 \mathrm{mmol} \mathrm{P} \mathrm{[g} \mathrm{chl} \mathrm{a} \mathrm{h}]^{-1}$ in this study) and suggest that the elevated P-uptake rates in the lake water can be at least partly explained by the presence of $C$. acidophila. Compared to P-limited phytoplankton from Lake Erken, the P-uptake rates in my study were high and lay well within the range of P-uptake rates considered to indicate extremely Plimited phytoplankton, i.e. 6 to $100 \mathrm{mmol} \mathrm{P}$ (g chl a h) ${ }^{-1}$ (Istvánovics et al. 1992).

Although alkaline phosphatase activity will be of limited use in the acquisition of $\mathrm{P}$ in very acidic lakes, previous studies showed that Chlamydomonas acidophila has phosphatase activity at pH 9 (Spijkerman et al. 2007) and, in general, as they become P-limited, algal cells typically exhibit an increase in alkaline phosphatase activity (Cembella et al. 1984). High alkaline phosphatase activities would subsequently be expected in lakes with a low SRP concentration and are often used as an indicator for P-limited algal communities (Beardall et al. 2001), but in the acidic mining lakes alkaline phosphatase activity (measured at $\mathrm{pH}$ 9) was highest in the lake with the highest SRP concentration. The increased alkaline phosphatase activities in the Fe-rich lakes is in accordance with increased phosphatase activities in the benthic community of the Fe-rich acid mining drainage of the Rio Tinto (Sabater et al. 2003). Also, in a saline, sulphaterich lake, high phosphatase activities were detected although SRP concentrations were high (Waiser \& Robarts 1995). In contrast, the alkaline enzyme concentrations were higher in Lakes 117, 113 and 111 than in Lake 107, and the activity and concentration of slightly acid phosphatases (those measured at $\mathrm{pH}$ 6) were also higher in lakes with lower SRP concentrations. Overall, large fluctuations were detected, and it is likely that the chemistry of the lake water more strongly influenced these fluctuations than the P-limitation of the algal community. Compared to other studies performed with phytoplankton in neutral lakes, the phosphatase activities at pH 9.0 in this study were approximately a 1000-fold (North et al. 2007) or 10-fold higher (Hantke et al. 1996). Such a comparison shows that alkaline phosphatase activity is relatively high in Fe-rich, acidic lakes. In contrast, phosphatase activities in Chlamydomonas acidophila grown in P-limited laboratory cultures that contained average iron concentrations (Spijkerman 2007) were well within the range of the activities at both $\mathrm{pH} 6$ and 9 described in this study, suggesting that high iron concentrations or low $\mathrm{pH}$ alone cannot explain this discrepancy.

In all P-enrichment experiments, algal biomass increased in water from all lakes and on all occasions. Assuming exponential growth, community growth rates enhanced by $\mathrm{P}$-addition can be calculated over the $7 \mathrm{~d}$ incubation period. This calculation estimates growth rates varying between 0.18 and $0.57 \mathrm{~d}^{-1}$, based on the increase of in situ chl a fluorescence. These values can be compared with P-enrichment experiments from Lake Erie for which in vivo fluorescence of 
chl $a$ is availabe (Moon \& Carrick 2007) - growth rates thus calculated ranged from 0.05 to $0.21 \mathrm{~d}^{-1}$. This comparison shows that the growth rates obtained in the Penrichment experiments of Fe-rich, acidic lakes were high compared to those obtained in the neutral Lake Erie and again show a significant response of the algal community to $\mathrm{P}$ addition.

There are some indications that the high ferric iron concentration (over $5 \mathrm{mmol} \mathrm{Fe} \mathrm{F}^{3+} \mathrm{l}^{-1}$ ) in the acid water drainage from a metal-rich stream in Spain is toxic for the eukaryotic community (Rowe et al. 2007). In addition, the presence of a Chlamydomonas species in the Rio Tinto river in Spain was negatively correlated with high concentrations of heavy metals (Aguilera et al. 2006). Above $\mathrm{pH} \mathrm{2,} \mathrm{ferric} \mathrm{iron} \mathrm{hydrolyses} \mathrm{to} \mathrm{Fe}(\mathrm{OH})^{2+}$ and $\mathrm{Fe}(\mathrm{OH})_{2}{ }^{+}$(see Welham et al. 2000), and this ferric iron forms complexes with phosphate. Ferric phosphate is more insoluble than ferrous phosphate, and, consequently, part of the SRP might consist of ferric phosphate complexes. In the lakes studied, concentrations of ferric iron were much higher than those of SRP, suggesting a potentially large concentration of ferric phosphate complexes. Indeed, P-enrichment experiments result in enhanced biomass in Lake 107, which contains relatively high SRP concentrations, but also 7 to $14 \mathrm{mmol}$ ferric iron $\mathrm{l}^{-1}$.

In addition to iron, $\mathrm{pH}$ might play a role in algal dominance, especially for Chlamydomonas acidophila. Although laboratory experiments have shown that the maximum growth rate of $C$. acidophila is similar at $\mathrm{pH}$ 2.3 and pH 3.2 (Gerloff-Elias et al. 2005, Spijkerman 2005), C. acidophila dominance was highest in Lake 117 and this agrees with the findings from Aguilera et al. (2006) that the presence of a Chlamydomonas species in the Rio Tinto, Spain was positively correlated with $\mathrm{pH}$.

\section{Seasonal observations}

In neutral lakes, $\mathrm{P}$ limitation becomes more pronounced with the progression of thermal stratification (e.g. Hochstädter 2000, Moon \& Carrick 2007). Although acidic lakes such as Lake 111 have thermal stratification (Tittel et al. 2003), previous studies have found little seasonal variation in plankton composition (Kamjunke et al. 2004). Little seasonal variation was also observed in the benthic algal community of the Rio Tinto (Sabater et al. 2003). In a previous study, no seasonal changes in SRP and only minor differences in the P-limitation state of epilimnetic Chlamydomonas acidophila in Lake 111 were found (Spijkerman et al. 2007). My study further indicates the minor influence of seasonal fluctuations on the ecology of the acidic lakes.
Trophic levels could not be properly separated in the P-enrichment experiments performed in this study. Among the algae living in very acidic lakes, many species have mixotrophic traits (J. Tittel, pers. com.). For example, phototrophic growth of Ochromonas sp. living in the acidic lakes was reported to be insignificant compared to phagotrophic growth (Tittel et al. 2003). Calculations showed that the mixotrophic alga Ochromonas sp. preys on Chlamydomonas acidophila in these acidic lakes, ingesting $7 \%$ of its own biomass per day (Tittel et al. 2003, supplementary material). This rate is confirmed in my study, in which the presence of a minimum of 10 Ochromonas sp. cells per C. acidophila cell will prevent (through predation pressure) excessive population growth of C. acidophila after P-enrichment. In addition, Ochromonas sp. most likely escapes P-limitation by preying on P-rich bacteria (Schmidtke et al. 2006).

\section{CONCLUSIONS}

Independently of SRP concentrations, $\mathrm{P}$ is likely the main nutrient limiting algal growth in very acidic lakes. Among the algal species living in the acidic lakes I studied, Chlamydomonas acidophila is most severely P-limited. C. acidophila is the dominant photoautotrophic alga in the acidic lakes, whereas Ochromonas sp., which dominates the biomass, is phagotrophic in nature and avoids P-limitation by engulfing P-rich particles (Schmidtke et al. 2006). The primary productivity in the acidic lakes is therefore most likely decreased by P-limitation.

Acknowledgements. I thank H. Behrend, S. Donath, B. Fach, C. Friedrich, H. Kampe, K. Schmidt, A. Schüler, C. Völker and B. Wagenhaus for assistance with the field work and laboratory analysis. H. Bukowsky is thanked for the Fe determination (University of Potsdam). D. Martin-Creuzburg is thanked for the C:N analysis (University of Konstanz) and the DFG (SP695/2) for funding.

\section{LITERATURE CITED}

Aguilera A, Manrubia SC, Gomez F, Rodriguez N, Amils R (2006) Eukaryotic community distribution and its relationship to water physicochemical parameters in an extreme acidic environment, Rio Tinto (Southwestern Spain). Appl Environ Microbiol 72:5325-5330

Beardall J, Young E, Roberts S (2001) Approaches for determining phytoplankton nutrient limitation. Aquat Sci 63: 44-69

Beulker C, Krumbeck H, Nixdorf B, Jander J (2002) Primärproduktion in sauren Gewässern unter dem Einfluss der Ressourcenlimitation. In: Deneke R \& Nixdorf B (eds) Gewässerreport (Nr. 7): Tagungsband zum Workshop, Biogene Alkalinitätsproduktion und Neutralisierung als 
ergänzende Strategie für die Restaurierung von extrem sauren Tagebauseen', BTUC-AR 3/2002. BTU Cottbus, Cottbus, p 107-112. Available at: www.tu-cottbus.de/ BTU/Fak4/publikationen/AR_3_02.pdf

Bissinger V, Jander J, Tittel J (2000) A new medium free of organic carbon to cultivate organisms from extremely acidic mining lakes ( $\mathrm{pH}$ 2.7). Acta Hydrochim Hydrobiol 28:310-312

Cembella AD, Antia NJ, Harrison PJ (1982) The utilization of inorganic and organic phosphorus compounds as nutrients by eukaryotic microalgae: a multidisciplinary perspective: Part 1. CRC Crit Rev Microbiol 10:317-391

$>$ Doi H, Kikuchi E, Hino S, Itoh T, Takagi S, Shikano S (2003) Seasonal dynamics of carbon stable isotope ratios of particulate organic matter and benthic diatoms in strongly acidic Lake Katanuma. Aquat Microb Ecol 33:87-94

Friese K, Herzsprung P, Witter B (2002) Photochemical degradation of organic carbon in acidic mining lakes. Acta Hydrochim Hydrobiol 30:1-8

Gerloff-Elias A, Spijkerman E, Pröschold T (2005) Effect of external $\mathrm{pH}$ on the growth, photosynthesis and photosynthetic electron transport of Chlamydomonas acidophila Negoro, isolated from an extremely acidic lake ( $\mathrm{pH}$ 2.6). Plant Cell Environ 28:1218-1229

Gyure RA, Konopka A, Brooks A, Doemel W (1987) Algal and bacterial activities in acidic ( $\mathrm{pH}$ 3) strip mine lakes. Appl Environ Microbiol 53:2069-2076

Hantke B, Domany I, Fleischer P, Koch M, Pless P, Wiendl M, Melzer A (1996) Depth profiles of the kinetics of phosphatase activity in hardwater lakes of different trophic level. Arch Hydrobiol 135:451-471

> Hochstädter S (2000) Seasonal changes of C:P ratios of seston, bacteria, phytoplankton and zooplankton in a deep, mesotrophic lake. Freshw Biol 44:453-463

Istvánovics V, Petterson K, Pierson D, Bell R (1992) Evaluation of phosphorus deficiency indicators for summer phytoplankton in Lake Erken. Limnol Oceanogr 37:890-900

Kamjunke N, Gaedke U, Tittel J, Weithoff G, Bell EM (2004) Strong vertical differences in the plankton composition of an extremely acidic lake. Arch Hydrobiol 161:289-306

Kamjunke N, Tittel J, Krumbeck H, Beulker C, Poerschmann J (2005) High heterotrophic bacterial production in acidic, iron-rich mining lakes. Microb Ecol 49:425-433

Kleeberg A, Schubert H, Koschorreck M, Nixdorf B (2006) Abundance and primary production of filamentous green algae Zygogonium ericetorum in an extremely acid $(\mathrm{pH}$ 2.9) mining lake and its impact on alkalinity generation. Freshw Biol 51:925-937

Lessmann D, Fyson A, Nixdorf B (2000) Phytoplankton of the extremely acidic mining lakes of Lusatia (Germany) with $\mathrm{pH}<3$. Hydrobiologia 433:123-128

Messerli MA, Amaral-Zettler LA, Zettler E, Jung SK, Smith PJS, Sogin ML (2005) Life at acidic $\mathrm{pH}$ imposes an increased energetic cost for a eukaryotic acidophile. J Exp Biol 208:2569-2579

Moon JB, Carrick HJ (2007) Seasonal variation of phytoplankton nutrient limitation in Lake Erie. Aquat Microb Ecol 48: $61-71$

Murphy J, Riley JP (1962) A modified single solution method for determination of phosphate in natural waters. Anal Chim Acta 27:31-36

Nixdorf B, Hemm M, Schlundt A, Kapfer M, Krumbeck H (2000) Braunkohletagebauseen in Deutschland: Gegenwärtiger Kenntnisstand über wasserwirtschaftliche Belange von Braunkohletagebaurestlöchern. Bericht des
Umweltbundesamtes, Berlin

North RL, Guildford SJ, Smith REH, Havens SM, Twiss MR (2007) Evidence for phosphorus, nitrogen, and iron colimitation of phytoplankton communities in Lake Erie. Limnol Oceanogr 52:315-328

Packroff G (2000) Protozooplankton in acidic mining lakes with special respect to ciliates. Hydrobiologia 433: 157-166

Redfield AC (1934) On the proportions of organic derivatives in sea water and their relation to the composition of plankton. In: Daniel RJ (ed) James Johnstone memorial volume. University of Liverpool, Liverpool, p 176-192

Rowe OF, Sanchez-Espana J, Hallberg KB, Johnson DB (2007) Microbial communities and geochemical dynamics in an extremely acidic, metal-rich stream at an abandoned sulfide mine (Huelva, Spain) underpinned by two functional primary production systems. Environ Microbiol 9:17611771

Ruecker J, Liepelt A (2003) Pigmentbestimmung in sauren Tagebaurestseen -Probleme und Lösungsansätze. Deutsche Gesellschaft für Limnologie (DGL) - Tagungsbericht 2002 (Braunschweig), Tutzing. Available at: www.tucottbus.de/BTU/Fak4/Gewschu/downloads/artikel/dgl_0 2_rueck_liep.pdf

Sabater S, Buchaca T, Cambra J, Catalan J and others (2003) Structure and function of benthic algal communities in an extremely acid river. J Phycol 39:481-489

Sas H (1989) Lake restoration by reduction of nutrient loading: expectations, experiences, extrapolations. Academia Verlag Richarz, St. Augustin

Schmidtke A, Bell EM, Weithoff G (2006) Potential grazing impact of the mixotrophic flagellate Ochromonas sp. (Chrysophyceae) on bacteria in an extremely acidic lake. J Plankton Res 28:991-1001

Spijkerman E (2005) Inorganic carbon acquisition by Chlamydomonas acidophila across a $\mathrm{pH}$ range. Can J Bot 83: 872-878

Spijkerman E (2007) Phosphorus acquisition by Chlamydomonas acidophila under autotrophic and osmomixotrophic growth conditions. J Exp Bot 58:4195-4202

Spijkerman E (2008) What physiological acclimation supports increased growth at high $\mathrm{CO}_{2}$ conditions? Physiol Plant 133:41-48

Spijkerman E, Bissinger V, Meister A, Gaedke U (2007) Low potassium and inorganic carbon concentrations influence a possible phosphorus limitation in Chlamydomonas acidophila (Chlorophyceae). Eur J Phycol 42:327-339

Stumm W, Morgan JJ (1970) Aquatic chemistry: chemical equilibria and rates in natural waters. Wiley-Interscience, New York

Tittel J, Bissinger V, Zippel B, Gaedke U, Bell E, Lorke A, Kamjunke N (2003) Mixotrophs combine resource use to outcompete specialists: implications for aquatic food webs. Proc Natl Acad Sci USA 100:12776-12781

> Tittel J, Bissinger V, Gaedke U, Kamjunke N (2005) Inorganic carbon limitation and mixotrophic growth in Chlamydomonas from an acidic mining lake. Protist 156:63-75

Waiser MJ, Robarts RD (1995) Microbial nutrient limitation in prairie saline lakes with high sulfate concentration. Limnol Oceanogr 40:566-574

> Weithoff G (2004) Vertical niche separation of two consumers (Rotatoria) in an extreme habitat. Oecologia 139:594-603

> Welham NJ, Malatt KA, Vukcevic S (2000) The effect of solution speciation on iron-sulphur-arsenic-chloride systems at $298 \mathrm{~K}$. Hydrometallurgy 57:209-223 